Available online at www.sciencedirect.com

\title{
Genetic identification in endodontic treated tooth root
}

\author{
A.T. Corte-Real ${ }^{a, *}$, M.J. Anjos ${ }^{\text {b }}$, L. Andrade ${ }^{\mathrm{b}}$, M. Carvalho ${ }^{\mathrm{b}}$, A. Serra ${ }^{\mathrm{b}}$, A.M. Bento ${ }^{\mathrm{b}}$, \\ C. Oliveira $^{b}$, L. Batista ${ }^{b}$, F. Corte-Real ${ }^{a, b}$, D.N. Vieira ${ }^{a, b}$, J.J. Gamero $^{c}$ \\ ${ }^{a}$ Faculty of Medicine, University of Coimbra, Portugal \\ ${ }^{\mathrm{b}}$ National Institute of Legal Medicine, Central Region Department Forensic Genetics Service, Portugal \\ ${ }^{\mathrm{c}}$ Faculty of Medicine, University of Cadiz, Spain \\ Received 21 August 2007; accepted 10 October 2007
}

\begin{abstract}
The tooth is an important sample in adverse forensic conditions. Its morphology and histology contributes for the preservation of the cellular components.

The endodontic root filling is a methodology used for preservation of tooth, in life, supporting a fixed rehabilitation. During endodontic procedure the pulp tissue and the inner layer of dentine are removed (the major nuclear DNA) and replaced for endodontic filling usually thermoplastic and cement. In the dentinal tubules, the odontoblats prolongations are preserved (mitochondrial DNA).

In this paper were studied endodontic tooth and the respective donor blood on compresses as reference samples. The samples were prepared. Teeth DNA extraction was made with a commercial kit, Purigene ${ }^{\mathbb{R}}$ DNA Purification System (PE Gentra), and quantified with an ABI Prism ${ }^{\mathbb{R}}$ 7000; amplification was performed with Identifiler ${ }^{\mathrm{TM}}$ PCR Amplification Kit (Applied Biosystems). In samples without STR profile was sequenced HVRI and HVRII. The samples were genotyped using an ABI Prism ${ }^{\circledR} 310$ and 3130 Analysers.

Results showed that with endodontic treated teeth were obtained STR profiles. Teeth are extraordinary samples in identification caseworks.

This study showed that even in roots with endodontic treatment were obtained full STR profiles, giving the possibility of individual genetic identification.
\end{abstract}

(C) 2008 Elsevier Ireland Ltd. All rights reserved.

Keywords: Identification; STR profile; Endodontic tooth root

\section{Introduction}

Forensic adverse conditions are usually associated with a high level of putrefaction and too degraded samples to perform genetics analyses. This is particularly true in mass disasters. The tooth is an important sample in different environments [1].

On the same source, usually you can find teeth with different quality: healthy and intact, with carious, with coronary and with endodontic root fillings (treatment to support a complex restoration or a fixed prosthetic rehabilitation often used). In same cases, there is only as biology sample an endodontic treated tooth.

During an endodontic procedure the pulp tissue and the inner layer of dentine are removed (the major contribute of nuclear DNA [1,2]) and replaced for endodontic filling usually

* Corresponding author at: Faculdade de Medicina, Largo D. Dinis, Coimbra 3000-213, Portugal. Tel.: +351 239854230.

E-mail address: a_cortereal@yahoo.com (A.T. Corte-Real). thermoplastic and cement. Into the dentinal tubules, the odontoblats prolongations are preserved from the aggressions (mitochondrial DNA) [2].

In this study were analyzed endodontic teeth root in order to aid the identification process.

\section{Material and methods}

In this study were analyzed 10 endodontic teeth and the respective donor blood on compresses as reference samples. Teeth were placed $1 \mathrm{~min}$ in sodium hypochlorite commercial bleach, and washed in sterile distilled water. Using a diamond cutting disc the samples were fragmented by longitudinal section. The endodontic filling was removed using a fine spoon excavator and the root channels were cleaned. The remaining hard tissues were isolated and reduced to powder in cryogenic mill [2-4].

Teeth DNA extraction was performed using the commercial kit Puregene ${ }^{\circledR}$ DNA Purification System (Gentra Systems) with some modifications: $0.06 \mathrm{~g}$ of dentine powder and bath at $55{ }^{\circ} \mathrm{C}$

1875-1768/\$ - see front matter (C) 2008 Elsevier Ireland Ltd. All rights reserved. doi:10.1016/j.fsigss.2007.10.094 
Table 1

Results obtained with the samples

\begin{tabular}{lcll}
\hline Samples & Quantification $(\mathrm{ng} / \mu \mathrm{l})$ & Identifiler & mtDNA \\
\hline 1 & 3.769 & Full profile & $*$ \\
2 & 8.182 & Full profile & $*$ \\
3 & 39.423 & Full profile & $*$ \\
4 & 3.042 & Full profile & $*$ \\
5 & 0.023 & No profile & HVRI HVRII \\
6 & 0.008 & No profile & HVRI HVRII \\
7 & 0.782 & Full profile & $*$ \\
8 & 0.385 & Full profile & $*$ \\
9 & 0.491 & Full profile & $*$ \\
10 & 0.355 & Full profile & $*$ \\
\hline
\end{tabular}

Note: *For the subject of this paper mtDNA analyses was not necessary.

overnight to better dissolution of proteins. DNA from compresses was extracted by the Chelex ${ }^{\mathrm{TM}} 100$ method [5].

DNA quantification was made with the Quantifiler ${ }^{\mathrm{TM}}$ Human DNA Quantification kit at the ABI Prism ${ }^{\circledR} 7000$ Sequence Detection System (Applied Biosystems).

Amplification of autosomic STRs (AmpFlSTR ${ }^{\circledR}$ Identifiler ${ }^{\mathrm{TM}}$ PCR Amplification Kit-Applied Biosystems) was made according to kit instructions. DNA quantity was adjustable to $3 \mathrm{ng} / \mu \mathrm{l}$ DNA in samples with high quantification values. PCR products were analyzed using an ABI Prism ${ }^{\mathrm{TM}} 310$ Genetic Analyser (Applied Biosystems).

In samples without STR profile Hypervariable Regions (HVRI: L15997-H16395; HVRII: L047-H408) were amplified with primers and amplification conditions according to Wilson et al. [6], using Taq Gold. Amplified fragments were purified by MicroSpin Sephadex HRS 300.

Sequencing reactions were performed in forward direction, using the ABI Prism dRhodamine Terminator Cycle Sequencing Ready Reaction Kit (Applied Biosystems), with the same primers used in amplification. Sequenced product was purified by $\mathrm{MgCl}_{2}$ /ethanol precipitation. Detection of sequencing fragments was carried out using an ABI Prism 3130 and analyzed in an ABI Prism 3130 Avant Automatic Sequencer.

\section{Results}

In eight of the samples it was obtained full STR profiles. In the others additional information was achieved in mitochondrial sequences (Table 1).
All extraction of references samples had good and correspondent STR profile and mitochondrial DNA.

\section{Discussion and conclusions}

Initially it was thought that the genetic analysis of the tooth could only be made from the pulp tissue [1,7]. Recently the analysis from its hard tissues has became more relevant [2-4]. The first choice is always for the intact and healthy tooth, however this option is not always available [2].

It was only expect a good mtDNA profile with endodontic treated tooth as a sample.

However, during endodontic procedure strong hydraulic forces are created within the dentinal tubules with odontoblast displacement [8]. The cell bodies of odontoblasts are displaced upward into the dentinal tubules.

Results (Table 1) showed that in teeth root with endodontic filling were obtained STR profiles. It is extraordinary samples in identification caseworks.

In conclusion tooth is a valuable source of DNA allowing genetic identification. Particularly even endodontic treated tooth should be collected when an intact tooth is not available.

\section{Conflict of interest}

None.

\section{References}

[1] A.A. Garcia, et al., Effect of environmental factors on PCR-DNA analysis from dental pulp, Int. J. Legal Med. 109 (1996) 125-129.

[2] A. Corte-Real, et al., DNA extraction from the pulp dentine complex of both with and without carious, Int. Congr. Ser. 1288 (2006) 710-712.

[3] R.M. Gaytmenn, S.D. Sweet, Quantification of forensic DNA from various regions of human teeth, J. Forensic Sci. 48 (2003) 622-625.

[4] H. Mórnstad, et al., Demonstration and semi-quantification of mtDNA from human dentine and its relation to age, Int. J. Legal Med. 112 (1999) 98-100.

[5] P.S. Walsh, D.A. Metzgar, R. Higuchi, Chelex ${ }^{\mathrm{TM}} 100$ as a medium for simple extraction of DNA for PCR-based typing from forensic material, BioTechniques 10 (1991) 91-98.

[6] M.R. Wilson, et al., Validation of mitochondrial DNA sequencing for forensic casework analysis, Int. J. Legal Med. 105 (1995) 68-74.

[7] K. Yamamoto, Molecular biological studies on teeth, and inquest, Forensic Sci. Int. 80 (1996) 79-87.

[8] H.O. Trowbridge, S. Kim, Pulp development structure and function, in: S. Cohen (Ed.), Burns-Pathways of the Pulp, Mosby, 1994, pp. 296-336. 